\title{
Perubahan Kebudayaan dan Perkembangan Musik Pop Minangkabau Di Indonesia
}

\author{
Firman Firman dan Agusli Taher \\ Fak. Ilmu Pendidikan Univ. Negeri Padang \\ Email : firman@konselor.org
}

\section{A. Pendahuluan}

Masyarakat Minangkabau menempati sebagian besar Daerah Tingkat I Propinsi Sumatera Barat dan termasuk salah satu suku terbesar dari keseluruhan penduduk Indonesia, selain suku Jawa, Sunda dan Madura. Perasaan sesuku bagi masyarakat Minangkabau didasarkan atas persamaan bahasa, asal usul pengelompokan serta penduduk yang homogen beragama Islam. Kehidupan masyarakat Minangkabau berlandasan adat basandi syarak, syarak basandi kitabullah (adat bersendikan syarak, syarak bersendikan kitabullah) dan mereka merasa tercela apabila disebut orang yang tidak beradat dan tidak beragama.

Adat Minangkabau mengatur kehidupan sehari-hari, dengan filosofis kehidupan masyarakat : alam takambang jadi guru (alam terbentang jadi guru), artinya alam dapat dipelajari, dipedomani, diatur dan dimamfaatkan untuk kemaslahatan umat manusia. Selanjutnya alam takambang memberikan warna dalam menetapkan norma dan nilai kehidupan masyarakat Minangkabau. Pepatah-petitih, maman, bidal, pantun dan gurindam dalam masyarakat 
Minangkabau disusun berlandaskan alam dan umumnya berbetuk metafora atau perlambangan yang secara idiomatis bersifat Agraris, nelayan, tukang, dan dagang.

Secara umum nilai yang terkandung dalam adat Minangkabau mengandung empat hal, yaitu : raso (rasa), pareso (periksa), malu (malu), sopan (sopan). Raso adalah pertimbangan pikiran mengenai baik-buruk, salah atau benar. Pareso adalah penyelidikan atau penilaian terhadap sesuatu. Malu adalah merasa tidak senang atau tercela karena berbuat sesuatu yang kurang baik. Sopan adalah hormat dan tertib menurut adat yang berlaku. Implikasi ke empat hal tersebut dalam kehidupan merupakan manifestasi dari budi pekerti yang baik dari seseorang, sesuai dengan pepatah : Nan kuriak kundi, nan merah sago, nan baiak budi, nan indah bahaso.

Salah satu ciri menonjol dari suku Minangkabau dibandingkan dengan suku bangsa lainnya, yaitu kebiasaan merantau dan sistem kekerabatan matrilinial dengan menelusuri ikatan kekerabatan melalui garis ibu. Merantau merupakan salah satu pola migrasi yang dilakukan oleh masyarakat Minangkabau. Masa silam kebiasaan merantau dilakukan oleh laki-laki sebagai tuntutan budaya, sesuai ungkapan : Karantau madang dihulu, babuah babungo balun. Karantau bujang dahulu, di rumah banguno balun (Karantau madang di hulu, berbuah berguna belum. Ke rantau bujang dahulu, di rumah berguna belum). Dewasa ini pola merantau masyarakat Minangkabau sudah berubah dan juga sudah dilakukan oleh perempuan untuk kepentingan pendidikan serta pekerjaan. Melalui merantau terjadilah kontak budaya antara masyarakat Minangkabau dengan masyarakat 
lainnya dengan latar budaya yang berbeda. Kondisi ini menyebabkan budaya Minangkabau menjadi Dinamik dan berubah sesuai dengan kebutuhan masyarakat.

Salah satu perubahan yang dapat diamati dewasa ini adalah musik pop Minangkabau. Masa silam syair lagu yang dinyanyikan tidak mengungkapkan perasaan serta pikiran secara terbuka dan biasanya diibaratkan kepada binatang, bunga serta gejala alam. Contoh : ayam den lapeh, sikua capang sikua capeh. Begitu juga dengan alat musik yang dimainkan lebih banyak menonjolkan ciri khas daerah. Dewasa ini perubahan demi perubahan ditemui di lingkungan masyarakat Minangkabau. Syair lagu sudah dilantunkan secara terus terang dan musik sudah mengadopsi musik ala Barat

Betapapun pesat perubahan dan kemajuan di bidang seni budaya, musik pop Minangkabau bertahan sejalan irama yang tercipta dari kemajuan itu sendiri. Musik pop Minangkabau menunjukkan identitasnya tersendiri, meskipun berbagai pengaruh turut memberi warna keberadaannya. Melalui tulisan ini menarik ditelusuri lebih lanjut bagaimana perkembangan musik pop Minangkabau di Indonesia dalam perubahan budaya.

\section{B. Perkembangan Musik Minangkabau Modern}

Perkembangan musik moderen Minangkabau tidak lepas dari karya-karya seni yang dilahirkan oleh pencipta dari beberapa dekade. Dalam bahasa Inggeris secara tepat kosa kata pencipta biasa digunakan untuk pengarang lagu, disebut composer, yang secara bebas dapat diartikan sebagai pembuat komposisi. Atau dalam bahasa yang lebih sederhana komposer dapat diartikan sebagai "tukang 
$a d u k^{\prime \prime}$. Sebenarnya istilah ini lebih tepat digunakan untuk pengarang lagu adalah komponis, akan tetapi hal ini jarang digunakan dalam kehidupan sehari-hari.

Sehubungan dengan hal itu, seorang komponis pada hakekatnya bukanlah pencipta dan mereka lebih banyak bekerja dalam mengatur komposisi, baik nada, harmoni dan motif, maupun kata dan kalimat dari lirik lagu. Oleh karena itu, komponis dalam proses berkarya lebih banyak dipengaruhi oleh wawasan (cognitif map) yang dimilikinya. Oleh karena itu komponis musik pop Minangkabau dalam melahirkan karya seni mereka akan berinteraksi dengan seni musik dan budaya masa lampau (tradisi) yang dijalaninya, serta kondisi budaya pada zamannya. Karya seni yang diciptakan merefleksikan kondisi masyarakat pada suatu dekade di Minangkabau.

Seberapa jauh nuansa musik tradisi dan musik kontemporer terwujud dalam sebuah karya musik akan sangat ditentukan oleh: (1) pendalaman, pembauran dan sublimasi yang dilakukan oleh seniman dalam berkarya, serta (2) peran serta dan apresiasi seni dari kubu tradisi dan modernis dalam zamannya. Kehilangan identitas musik dari suatu masyarakat disebabkan oleh kurangnya enkulturasi budaya. Keberhasilan enkulturasi budaya ditentukan oleh pelaku, tujuan, teknik, serta waktu transmisi budaya dilakukan dari satu generasi ke generasi berikutnya di lingkungan masyarakat Minangkabau.

Apabila terjadi ketertinggalan unsur klasik/tradisi dalam sebuah karya musik disebabkan oleh: (1) kurangnya apresiasi dan sosialisasi budaya oleh budayawan yang lebih menguasai seni klasik, (2) pengaruh gelegar seni musik introduksi, dan (3) perubahan tata nilai dan selera dari konsumen musik. 
Dengan menempatkan pengarang sebagai komposer, bukan sebagai pencipta, maka kita akan lebih mudah memahami bahwa siapa pun komposer, atau musik etnis mana pun di dunia ini, maka semuanya akan mengalami "keterpengaruhan" karya cipta.

Kontak budaya antar etnik serta pengaruh pola pembangunan yang bersifat sentralistik masa Orde Baru di Indonesia, ikut mewarnai karya seni komponis lagu pop Minangkabau. Bagaimana menjelaskan secara tepat, apabila kita ditanyakan, yang mana musik dan lagu Indonesia. Apakah lagu Mawar Berduri karya A. Riyanto atau lagu Widuri karya Adriadi itu lagu Indonesia ? Kalau YA, tentu lagu-lagu tersebut mestinya berakar ke dalam musik dan lagu etnik bangsa Indonesia. Oleh karenanya, perlu dipertanyakan lagi, apakah kedua lagu tersebut membawa nafas lagu Minang, Jawa, Sunda, Batak, Maluku, Aceh, Kalimantan dan lainnya ? Yang mana lagu Minang ?

Para akademisi musik memang mampu menjelaskan secara tepat, bahwa lagu Minang itu dicirikan oleh tangga nada yang Pentatonik, sedangkan lagu pop Indonesia bertangga-nada Diatonik. Akan tetapi, perlu kita pertanyakan lagi, kemana berakarnya lagu laruik sanjo dan ayam den lapeh? Apakah cukup senafas dan sewarna kedua lagu pop Minang legendaris ini dengan Rabab, Dendang Pauah, Indang, Saluang Darek, Salawat Dulang, Sirompak, musik tari, Palayaran, atau lagu-lagu tradisi ketika orang-orang kampung dulu mem-bobok-bobok-kan anak di buaian? Pertanyaan lain, kenapa orang Minangkabau yang seseni-sebudaya, yang berdomisili dalam kawasan yang relatif sempit itu memiliki ragam musik yang amat besar ? Hal ini sulit menjawabnya ! Yang pasti adalah ratusan tahun yang 
lalu, nenek moyang masyakat Minangkabau terbuka terhadap pembauran seni musik. Mereka lebih mengerti akan perlunya perbedaan dan kreativitas, agar tidak terjadi stagnasi berkesenian, sebagai manifestasi dari "Basilang kayu dalam tungku, disinan api mangko iduik" (Bersilang kayu dalam tungku, di situlah api dapat menyala). Agaknya mereka lebih arif dan toleran terhadap dinamika dan perubahan, sehingga memberikan peluang kepada kreativitas untuk lebih jauh menembus ruang dan waktu.

Kondisi itu sebagai penyebab, musik Gamad dapat diterima sebagai musik Minang oleh masyarakat Minangabau, meskipun gamad adalah musik Spanis berbahasa Minang, selanjutnya masyarakat Minangkabau ternyata tak canggung pula mengadopsi tari balanse madam secara total dalam bagian tak terpisahkan dari kesenian masyarakat Minangkabau.

\section{Keorisinilan Karya Cipta}

Pengarang lagu pada prinsip bekerja mengkombinasikan satu ide dengan ide lainnya. Ide tidak jarang sebagai hasil dari kontak budaya dengan etnik lainnya, sehingga menghasilan lagu klasik dan moderen di Minangkabau. Semua orang pasti menganggap bahwa lagu Si Ringgit-Dua Kupang adalah lagu klasik etnik Deli, meskipun notasinya sama dengan lagu pengiring Tari tradisi bangsa Thailand di propinsi Chiang Rai, yang hampir selalu ditampilkan dalam acara Cultural Show. Begitu juga halnya dengan lagu: Kampuang Nan Jauh Dimato adalah lagu orang Minangkabau. Namun, apa bedanya semua notasi lagu tersebut dengan lagu pop Indonesia (lagu Anak-Anak) "bermain layang2" ! Bahkan, menurut Asbon Majid, lagu tersebut adalah lagu Country. 
Orang Payakumbuh (salah satu daerah di Minangkabau) akan bersikukuh mengatakan lagu klasik si rompak adalah lagu sub etnik mereka, akan tetapi kenapa lagu tersebut menyimpan penggalan notasi Sunda atau Jawa. Semua kita yakin lagu langkisau adalah lagu Minang, akan tetapi kenapa perjalanan accord-nya membawa kita pada suasana musik santana, atau kenapa lagu yo lah lamo pun memiliki selarik nada Mandarin dalam penggalan lirik : "Cubolah Agiah Rokok Den Ciek" (meskipun Yusaf Rahman menyatakan bahwa penggalan nada tersebut ada dalam lagu tradisi orang Pesisir Selatan).

Kesamaan bagian tertentu dari lirik dan musik buah karya pengarang, sebagai hasil dari kontak budaya, selanjutnya menyebab terjadinya difusi budaya. Apabila ditelusuri lebih lanjut akan ditemukan sejak kapan dan bagaimana terjadinya kontak antara satu masyarakat yang berbebda budaya tersebut terjadi. Di sisi lain difusi budaya tersebut adalah konsekwensi dari hakikat bahwa pengarang lagu itu hanyalah komposer, bukan pencipta ! Alam bawah sadar seorang seniman musik biasanya penuh dengan nada-nada, yang berasal dari beragam musik etnik dan musik komtemporer yang pernah didengarnya, yang terangkat kepermukaan ketika proses mencipta sedang dimulai. Dalam kondisi ini, difusi budaya akan ditemukan dari berbagai karya seni dalam masyarakat. Difusi budaya setelah dikonsusi oleh suatu masyarakat dari latar eknik serta budaya tertentu memberikan kontribusi pengembangan kekayaan seni budaya masyarakat.

Kritik terhadap perkembangan lagu Minang sering dilandasi oleh acuan yang campur aduk, serta kurang dibekali oleh pemahaman yang baik tentang perbedaan lagu klasik dan lagu pop Minang. Pada prinsipnya, lagu tradisi/klasik 
bersifat dan bernuansa konservatif. Karenanya, lagu tradisi relatif tidak memerlukan inovasi, eksperimentasi, serta kurang atau tidak ada unsur komersialnya, dan ditampilkan untuk menunjukkan identitas etnik. Secara fanatik, keaslian dan ketradisionilannya sering dipertahankan sebagaimana adanya, sehingga ketika Yan Juneid mem"populer"kan lagu Gamad, cukup banyak orang yang menggugat. Padahal secara jujur harus diakui, bahwa akibat "sentuhan Yan Juneid" lah lagu Gamad masuk gedongan, serta keluar dari keterisolirannya. Sebaliknya, lagu pop Minang modern bercirikan: amat-sangat dinamik, eksperimentatif, inovatif, dan memerlukan adanya kejutan-kejutan musik, agar bisa tampil beda dan memiliki muatan-muatan komersial yang lebih tinggi, karena musik pop sudah memasuki dan menjamah wilayah entertainment dan industri musik yang penuh dengan kompetisi dan risiko bisnis.

Di sisi lain, pada prinsipnya perkembangan musik pop tidak terlalu ditentukan oleh produser, sebagaimana yang dianggap banyak orang selama ini. Perjalanan musik pop lebih ditentukan oleh perubahan selera konsumen musik, yang memiliki banyak alternatif musik sebagai dampak globalisasi, dan mungkin juga sebagai akibat perubahan tatanan sosial dan budaya.

Sehubungan dengan hal itu, pemasaran salah satu aspek yang turut mentukan perkembangan musik pop Minangkabau. Pemasaran adalah suatu proses sosial dan manajerial di mana individu dan kelompok mendapatkan kebutuhan dan keinginan mereka dengan menciptakan, menawarkan dan bertukar sesuatu yang bernilai satu sama lain. Adapun tujuan pemasaran adalah mengenal dan memahami pelanggan sedemikian rupa sehingga produk cocok dengannya 
dan dapat terjual dengan sendirinya. Idealnya pemasaran menyebabkan pelanggan siap membeli sehingga yang tinggal hanyalah bagaimana membuat produknya tersedia. Sedangkan proses pemasaran terdiri dari analisa peluang pasar, meneliti dan memilih pasar sasaran, merancang strategi pemasaran, merancang program pemasaran, dan mengorganisir, melaksanakan serta mengawasi usaha pemasaran.

Pemenuhan selera masyarakat Minangkabau atau masyarakat etnik lainnya sebagai konsumen musik pop Minangkabau, bukan tidak dicoba mengangkat musik tradisional ke dunia rekaman, baik dalam bentuk aslinya, atau yang sudah dipoles dengan nuansa musik kontemporer. Pirin Asmara (Rabab), Harun (Dendang Pauah), Fir Arjuna (Salawat Dulang), Melati dan Misramolai (Saluang Darek), Udin Pono dan Syahrudin Syarif (Gamat asli) adalah nama-nama pelaku musik tradisi, yang dicuatkan oleh produser rekaman dalam periode dua dasawarsa ini. Di samping itu, bukan pula tidak dilakukan pengulangan kembali menampilkan musik Gumarang kedalam percaturan musik era 1990-an ini, bahkan Gumarang sendiri melempar album bertajuk nan kanduang-Gumarang pada tahun 1996, dengan vokalis Syaiful Nawas, Juni Amir, Asbon, Zwarman Nizwar, dan Yetty Djalil.

Walaupun demikian kritik demi kritikan dilontarkan terhadap perkembangan musik pop Minangkabau sekarang ini, diantaranya: (1) karya seni kurang mengakar kepada budaya, (2) berorientasi komersial, (3) kurang agamis, (4) menyimpang dari adat, dan (5) alat musik yang digunakan tidak asli, seperti saluang, bansi, talempong, ataupun pupuik batang padi. Alat musik yang digunakan pemusik sekarang adalah produk Barat seperti orgen, piano, dan malah 
menggunakan MIDI, sehingga keasliannya hilang. Satu hal lagi yang menjadi acuan: Musik Minang sekarang tidak sehebat dan se-orisinil Gumarang. Cuma yang selalu mengambang dan tidak jelas, bagaimana "kisahnya" sampai kepada opini yang demikian.

Apabila dianalisis lebih lanjut kritik tersebut tidak dapat disimpulkan hanya demikian. Proses berkesenian sebagian besar dimulai dari peniruan-peniruan, yang makin lama-makin mengarah pada penemuan jati diri seorang komponis, atau pun arranger. Dengan demikian, seorang komponis tidak akan pernah lupa berkaca banding dengan pendahulu dan seniornya yang melegenda karya-karyanya, atau pun musik etnik di luar budayanya, yang telah menjadi lagu abadi (Ever green songs). Kadang-kadang mereka berkaca pada Asbon atau Nuskan Syarif, Tarun Yusuf, dan Masrul Mamuja, sedangkan di lain waktu mereka bergumul dengan karya A. Riyanto, Ismail Marzuki, Rinto Harahap, Oma Irama, Ajis Sutan Sati, bahkan Stevie Wonder ataupun John Lenon sekalipun.

Apabila kita simak karya-karya besar orkes Gumarang di Minangkabau, maka lagu Laruik Sanjo, Ayam Den Lapeh, Sayang Tak Sudah, Baju Kuruang, Si Nona, Buruak Pinto, Kato Rang Sisuak, Nan Bagala, Ondeh Yo Niang, Sansaro, Bujang Kirai, akan mencuat ke permukaan. Dari orkes Kumbang Cari akan “tacilak" lagu Diak Kanduang, Mayang Taurai, Pasan Mandeh, Kumbang Cari, Bareh Solok, Lansek Manih, Lamang Tapai, Ginyang Mak Taci, dan Bahondoh Pondoh. Dari orkes Taruna Ria, akan muncul lagu Rantak Kudo, Kampuang Jauh Dimanto, Si Nandi-Nandi, Malin Kundang, Lompong Sagu sebagai lagu legendaris. Dari Zainal Combo dan grup-grup sezaman-nya, akan muncul lagu Bapisah Bukan 
Bacarai, Kelok 44, Ubekkan Denai, Cogok Mancogok, Kasiah Tak Sampai, Hujan, Batu Tagak atau Usah Diratoki, Lintuah, Sadiah, dan Gasiang Tangkurak.

Berdasarkan uraian tersebut di atas, apabila disimak melodi dan syairnya dan dikaitkan dengan acuan ideal (berciri adat, budaya, agama, filosofi), maka apa bedanya lagu-lagu tersebut dengan lagu karya komponis era 1980-1990-an ? Silahkan disimak karya-karya B. Anduska (Guguak Manyambah dan Pandang Tak Sudah); Udin Brt (Di kampuang-Raso Marantau, Tangih Disalo Galak), Yon Idrus (Tarumuak dan Dirintang Janji), Asben (Kolak Sarabi, Ubek Daun Kacang), Rhian D'Kincai (Ilalang Jadikan Bungo, Bungo Lambah Gumanti), Nedi Gampo (Sapayuang Bajauh Hati, Lenyai), Zul Azham (Ratok Padi Ampo, Padiah Diseso Janji), Das Tanjung (Ratok Kain Lusuah, Gamang Dek Pananggungan), dan lainnya.

Kalau Asbon, Anas Yusuf, Nuskan Syarif, Masrul Mamuja, Tarun Yusuf, Yusaf Rahman, dan Ibenzani berhasil dengan format lagu Ratok bertemakan cinta dan nasib, maka komponis era 1980-1990-an seperti Udin Brt, Rhian D'Kincai, B. Anduska, Zul Azham, ataupun Freddy Pitopang, juga tidak akan jauh-jauh berkesenian dari tema di atas. Kalau Asbon berhasil dengan garahnya dalam lagu Nan Bagala, Nuskan Syarif dengan Bahondoh-pondoh, Zai Syafei dengan Tukang Tumbok dan Si Roih, maka seorang Nedi Gampo akan muncul pula dengan Aki Suak dan Si Jawinar-nya. Kalau lebih keras "garah kudo"-nya Nedi Gampo, itu hanya karena zaman dan selera pun sudah berubah, karena "pagar budaya" pun mungkin kurang mampu berbuat banyak, sejak parabola pun masuk desa. 
Kalau dikritik lagu Ratok itu cengeng, itu hanya karena lagu ala "Busungkan Dadamu" (lagu-lagu bernafaskan lagu Mars) tidak laku dijual dan si kritikus pun tak suka mendendang-dendangkannya, sebab si kritikus pun, masih demam dengan lagu Say you-say me-nya Leonel Richie. Kalau dikritik lagu Garah Kudo, itu mungkin karena masyarakat mengisyaratkan: "Bikin garah kudo nan labiah bagak", bila dilihat dari semangat mereka membeli kaset dan antusiasnya mereka menonton Nedi Gampo show. Inilah tantangan terbesar dalam mengimplementasikan : Adat basandi syara'-syara' basandi kitabbullah" sepanjang masa. Yang patut digaris-bawahi adalah: Demand terhadap produk musik, biasanya tidak mampu direkayasa oleh pelaku musik, akan tetapi ditentukan oleh konsumen musik, sedangkan pebisnis produk musik biasanya menyesuaikan ragam produknya dengan apa yang dikehendaki oleh masyarakat pembeli. Dengan demikian "menyehatkan" kinerja pelaku musik atau pebisnis musik harus dimulai juga dari menyehatkan konsumen musik.

\section{Pergeseran Pusat Industri Musik Minang}

Gelegar musik pop Minang dimulai dari ibu kota, ketika album pertama orkes Gumarang di piring-hitamkan pada tahun 1955. Daya pukau Gumarang makin tajam ketika Nurseha mulai bergabung pada tahun 1957 dan sukses besar dengan hitnya ayam den lapeh. Pada tahun 1960-1963, lagu-lagu Minang makin membanggakan Sumatera Barat, ketika Kumbang Cari tampil lain dengan kekhasan lagu dan pukau-an vokal Nuskan Syarif dan Elly Kasim. Dalam periode yang hampir bersamaan dengan kemunculan Kumbang Cari, Oslan Hosen dengan 
Taruna Ria pimpinan Zaenal Arifin juga saling berpacu mencari tempat di hati orang Minang. Kedua orkes Minang ini sama-sama berhasil menjaring penggemar.

Meskipun demikian, ada perbedaan prinsip antara kekuatan orkes Gumarang dengan Kumbang Cari dan Taruna Ria. Orkes Gumarang lebih bertumpu pada kekuatan beat dan warna musik dibandingkan kekuatan lagu. Ini berkaitan dengan obsesi Asbon: "Lagu Minang harus mendunia". Secara arif dan brilian personil Gumarang memang pas menentukan pilihan bahwa beat dan hentakan musik akan lebih komunikatif hadir diantara beragam etnik, bahkan mampu merambah keluar Indonesia. Itu juga yang terjadi dengan Musik India, Blues, Country, Rock 'n roll, Cha-cha, Samba dan lain-lain. Kekuatan beat dan musik memang lebih mampu mendunia dari kekuatan lagu.

Sebaliknya Kumbang Cari dan Taruna Ria, agak menganak emaskan lagu yang lebih ber-iro Minang dalam karya musiknya, sehingga kehadiran Kumbang Cari dan Taruna Ria relatif lebih lokal spesifik. Bagi orang Minang, sulit mencari tandingan Nuskan Syarif sebagai pencipta lagu bernafaskan Minang. Inipun diakui oleh Bapak lagu Minang modern, Asbon Majid. Akan tetapi, orang non Minang lebih mudah menerima suguhan Gumarang dibandingkan Kumbang Cari, karena musik dan lagu Gumarang lebih universal. "Ilau-ilau khas Minang akan sulit ditemukan dalam lagu-lagu Gumarang", karena memang Asbon cs memformat musiknya bukan hanya untuk orang Minang. Malah Asbon bilang: Lagu Gumarang bukan untuk orang Padang, Pariaman, Pasisia, Darek, atau sub etnik Minang lainnya, tetapi dirancang lebih luas: Untuk orang Sumbar. 
Selanjutnya, ketidak-hadiran Kumbang Cari akibat penugasan Nuskan Syarif ke Irian Barat selama tahun 1963-1967, digantikan oleh Zainal Combo dengan suguhan musik yang lebih komersial, berpilar penyanyi Elly Kasim, Tiar Ramon, Lily Syarif, dan Yan Bastian.

Secara khusus, dari periode 1955-1974, ada dua hal yang patut dicatat, yaitu : (1) bisnis musik pop Minang berpusat di Jakarta, dan (2) hampir tidak satu pun alat musik tradisional digunakan dalam setiap album yang dilepas ke pasaran. Alat musik tradisional untuk pertama kali diintrodusir oleh Zainal Combo ketika merekam album Elly Kasim di Singapura pada tahun 1975, ketika tambilang tanti batanti masuk dapur rekaman. Alat musik tersebut adalah saluang.

Pada tahun 1974, Yan Juneid dengan Lime Stone's-nya melepas album Gamad sarunai aceh. Inilah untuk pertama kali, pusat industri musik Minang mulai berbagi pengaruh antara Jakarta dan Padang. Sukses Yan Juneid, memicu terjadinya "Booming" bisnis lagu Minang di Sumatera Barat. Belasan produser kaset bermunculan di Kota Padang mencuatkan beberapa artis lainnya, seperti Asben, Syamsi Hasan, Yun Bur, Nel Yulius, Melati, dan Rosnida Ys. Dan, Studio Edo Record pantas dicatat sebagai stuidio paling berjasa dalam menopang industri musik Minang di Kota Padang, periode 1974-1980 ini.

Meskipun telah begitu spektakuler perkembangan lagu pop Minang dalam periode 1970-an di Padang, akan tetapi lagu Minang belum mampu menjadi tuan rumah di ranah Minang, bila diukur dari omset penjualan kaset dan respon masyarakat yang dapat diukur dari acara kenduri dan malam-malam kesenian. Pesona lagu Barat, Koes Plus, D'Loyid, Panbers, Broery, Edy Silitonga, Emillia 
Contessa, atau Mus Mulyadi, masih belum tergoyahkan oleh lagu Minang. Penyanyi band dan penyumbang-penyumbang nyanyi dalam acara kenduri ketika itu kebanyakan menampilkan diri sebagai Broery-Padang atau Koes Plus-Padang, atau kadang-kadang bermunculan pula Mick Jagger-Minang dan John Lenon-Minang.

Memasuki tahun 1980-an, perkembangan musik Minang mulai senyap, baik yang ada di Jakarta maupun di Sumatera Barat. Produser yang masih tersisa hanyalah Tanama Record. Era 1980-an ini dapat disebut sebagai masa-masa paling suram dan miskin kreativitas, meskipun pada periode inilah unsur talempong dan bansi dimasukkan dalam kemasan musik pop Minang. Di masa ini, Tiar-Indo Jati amat dikenal sebagai pemain bansi yang sering keluar-masuk dapur rekaman. Pada tahun 1994, album kasiak 7 muaro dilempar ke pasaran. Album eksperimentatif Agus Taher-Zalmon-Ferry Zein ini menandai menggelegarnya kembali "Booming" musik minang kedua. Kejutan album musik Kasiak 7 Muaro, sebenarnya ditopang oleh fenomena musik-lagu-penyanyi, sebagai fenomena tigo tungku sajarangan. Pemusik Ferry Zein sebagai seorang yang kurang mengenal musik Minang dan lebih banyak menggeluti musik klasik Internasional dengan kekuatan khusus dalam permainan piano, ketika menggarap album kasiak 7 muaro "dipaksa" meleburkan diri dalam suasana Minang. Hal itu mengakibatkan musiknya terasa lain dan tampil beda, apalagi di dalam musik album tersebut mulai diperkenalkan Sound Effect secara pas. Lagu-lagu pun ditampil dengan kekuatan dan ciri baru, yaitu puitisasi lagu yang lebih mampu menghadirkan suasana batin, sehingga ketika berpadu dengan warna vokal dan suasana Pauah dan tradisi yang dibangun Zalmon, maka muncullah sebuah kemasan lagu yang terasa aneh, lain, dan beda dengan 
yang biasa diperdengarkan.

Kelainan penyajian itulah yang menjadi kejutan musik, dan merupakan fenomena blantika musik Minang. Fenomena ini dapat dilihat dari perjalanan karir musik Zalmon. Dia telah mengenal bilik rekaman sejak tahun 1974, akan tetapi baru tahun 1994, namanya meroket sebagai penyanyi papan atas yang masih bertengger di singgasananya dalam kurun waktu yang amat lama. Pelajaran yang dapat dipetik dari fenomena di atas adalah musisi harus rajin menemukan inovasiinovasi baru yang lebih mampu memberikan kejutan. Disini, kita pun harus siap menerima pembaharuan itu. Kritisi pun mesti menempatkan diri dalam proses eksperimentasi dan inovasi tersebut. "Jangan layu-kan kuncup sebelum sempat berkembang"

Perlu dicatat dalam periode 1990-an ini adalah: (1) makin kokohnya kota Padang sebagai pusat industri musik Minang, serta semakin jauh meninggalkan Jakarta, bahkan upaya-upaya "pengambil-alihan" pusat bisnis ini oleh kelompok produser Jakarta melalui Hetty Koes Endang, Betahria Sonatha, Edy Silitonga, Yenny Rory, Victor Hutabarat, Hetty Sitorus, Van Bintang, dan lain-lain tidak mampu menghadapi dominasi Zalmon dan kawan-kawan, (2) beberapa orang seniman dan pelaku seni mulai unjuk gigi sebagai produser, (3) lagu Minang menjadi tuan rumah di ranah Minang, (4) terjadinya perubahan dalam penataan lagu, sehingga periode ini lebih menonjol dengan kegandrungan puitisasi lagu, dan meninggalkan pola pantun dalam syair lagu, (5) sound bansi dan talempong, serta sound effect sudah menjadi kebutuhan dalam aransement musik, (6) munculnya Zalmon dan Anroys sebagai idola baru untuk lagu manis, dan Nedy Gampo 
sebagai idola lagu garah, (7) makin berkembangnya pola "Art is not only for art", tetapi dunia musik juga cukup pantas dijadikan profesi, dan (8) terpilihnya lagu Minang sebagai penerima Anugrah HDX tahun 1995 (nan tido manahan hati), selanjutnya bugih lamo (1996) berdasarkan kriteria lagu terlaris yang direkam diatas pita HDX. Apabila diukur dari total masyarakat Minang hanya sekitar 8.5 juta di seluruh Indonesia, sedangkan warga Sunda dan Jawa mendekati 30 dan 40 juta orang, maka anugrah HDX itu membuktikan bahwa lagu Minang masih lebih tinggi berkibarnya di tanah air.

Periode ini juga ditandai oleh dua hal. Pertama makin menjamur dan beragamnya pelaku musik, baik penyanyi, pecipta, arrangger, operator, produser, dan orgen tunggal,. Dari kalangan wartawan dikenal Syarifudin Arifin dan Rhian D’Kincai sebagai pengarang lagu, sedangkan Yusril Ardanis Sirompak, Pinto Janir telah mulai mampu melahirkan lagu karyanya sendiri, Kedua, pejabat makin apresiatif dan makin tidak "malu-malu" untuk berkesenian pop Minang (Gamawan Fauzi SH, muncul dengan 2 albumnya, yaitu bungo lambah gumanti dan jantuang hati denai, sedangkan Achyarli Djalil SH, menyempatkan diri menciptakan lagu mambangkik batang tarandam, Pada tahun 1998, Drs. F. Anton, disamping menghasilkan beberapa karya, juga tampil sebagai penyanyi, sekaligus menyanyikan lagu badoncek-nya Ir. Nasrul Syahrun, mantan Bupati Padang Pariaman. Pada tahun 1999, Kanwil Dekdikbud pun telah berani turun tangan menggelar Festifal Karya Cipta Lagu Minang, sekaligus memproduksi 10 lagu terbaik Festifal tersebut dalam sebuah album rekaman yang terbilang sukses. Ini pertama kali Institusi Pemerintah mau memprakarsai sebuah pergelaran seni- 
sekaligus produksi album musik. Selanjutnya pada tahun itu pula Gubernur Sumbar mau memberikan anugrah Seni Musik kepada seniman angkatan baru. Juga, pada tahun 1999 ini pula, atas prakarsa Bupati Solok, akan diselenggarakan Festifal Karya Cipta Lagu Minang bernafaskan Islam, sebagai bagian dari penyelenggaraan MTQ di Solok bulan Oktober 1999.

Keberhasilan perkembangan musik dalam era ini juga ditopang oleh beberapa wartawan yang memiliki kepedulian tinggi terhadap musik Minang, seperti Rhian D'Kincai, Yusril Ardanis Sirompak, Syarifuddin Arifin, Pinto Janir, Alwi Karmena, serta pengamat musik B. Anduska. Dan, marak dan berkembangnya industri musik Minang periode 1990-an ini, juga amat-sangat ditopang oleh studio ASKI Padang Panjang.

\section{E. Penutup}

Seni musik adalah produk zamannya. Ia selalu berubah dan berkembang sesuai dengan cita rasa dan tata nilai yang ada dalam masyarakat pada zamannya. Perubahan tersebut makin tak terbayangkan dengan makin pesatnya perkembangan iptek dan komunikasi. Dengan demikian, akan sulit dan tak mungkin menilai perkembangan musik sekarang dengan kacamata dan format masa lalu.

Kritik dan opini terhadap pelaku dan perkembangan musik pop Minang perlu dilakukan secara hati-hati dan proporsional agar lebih mampu meningkatkan kiprah musik minang menghadapi dahsyatnya arus musik non Minang. Perubahan dan perkembangan seni musik pun harus dicermati dan disikapi sebagai perubahan budaya itu sendiri sehingga "pemasungan" kreativitas dalam musik pop 
Minang dengan format masa lalu akan sia-sia, apabila tidak ada pembenahan dalam mengantisipasi perubahan budaya.

Kenyataan bahwa pusat industri musik Minang telah berpindah dari Jakarta ke Padang perlu dicatat sebagai keberhasilan para musisi Sumbar. Dan, sukses itu terjadi tanpa adanya bantuan dan campur tangan pihak-pihak yang bertanggung jawab dalam melestarikan seni musik Minang, kecuali studio ASKI Padang Panjang. Kritik-kritik yang terlontarkan berbagai pihak, perlu disikapi secara arif oleh pelaku musik Minang modern, bahwa tuntutan masyarakat kita makin tinggi terhadap kualitas karya cipta, dengan tetap mampu melestarikan akar budaya Minangkabau dalam buah karya.

\section{Daftar Kepuatakaan}

A.A. Navis, (1986), Alam Terkembang Jadi Guru : Adat dan Kebudayaan Minangkabau, Jakarta : Grafiti Pers.

Amir M.S. (1997):Adat Minangkabau. Pola dan Tujuan Hidup Orang Minangkabau. Jakarta: Mutiara Sumber Widya.

Boas,F (1955) : Primitive Art. New York: Dover

Ishikawa, K. dan David, J.L (1992) : Pengendalian Mutu Terpadu. Bandung: Penerbit P.T. Remaja Rosdakarya.

McLeod,N.(1974) : Ethnomusicological Research and Anthropogy.Annual Review of Anthropology 3 : 99-116

Naim, Mochtar, (1986) : Dampak Sosial Budaya dari Merantau terhadap Pembangunan Daerah Sumatera Barat, dalam Jurnal Penelitian dan Pengabdian kepada Masyarakat. Univ.Andalas No. II September 1986.

, (1991) : Kebudayaan Daerah dan Kebudayaan Nasional. Jakarta : Kongres Kebudayaan Nasional. 
Nasrun, M. (1971) : Dasar Filsafah Adat MInangkabau. Jakarta : Penerbit Bulan Bintang. 